\title{
MACARBOMYCIN, AN INHIBITOR OF PEPTIDOGLYCAN SYNTHESIS
}

\author{
Jrro Suzuki*, Makoto Hori, Tetsuji Saeki \\ and Hamao UMEZAwa \\ Institute of Microbial Chemistry, Shinagawa-ku, Tokyo, Japan
}

(Received for publication October 13, 1971)

\begin{abstract}
Macarbomycin, a new antibiotic active against gram-positive bacteria, was shown to inhibit the synthesis of peptidoglycan both in vivo and in vitro. The detailed mechanism of action is discussed.
\end{abstract}

Macarbomycin is a polysaccharide antibiotic isolated from a strain of Streptomyces phaeochromogenes by UMEZAWA and his co-workers in 1964.1). It contains phosphorous and is a member of the group including moenomycin ${ }^{2)}$, prasinomycins ${ }^{3)}$ and diumycins ${ }^{4)}$. These antibiotics are all active against gram-positive bacteria. Moenomycin and prasinomycins are distinguished from marcarbomycin by the fact that the former two liberate 6-deoxyglucosamine on acid hydrolysis. Both macarbomycin and diumycins do not contain 6-deoxyglucosamine and their chemical relationship is still obscure.

Prasinomycins $5^{57}$ and moenomycin ${ }^{6}$ ) have been shown to inhibit peptidoglycan synthesis by bacteria. We studied the effect of macarbomycin on the growing cells of Staphylococcus aureus and compared the mechanism of action of this antibiotic in inhibiting the peptidoglycan synthesis in vitro with that of vancomycin. Vancomycin was reported to bind to the cell wall resulting in inhibition of peptidoglycan synthesis, but experimental evidence to show the binding of macarbomycin to the cell wall was not obtained. This antibiotic directly inhibited the peptidoglycan synthetase.

\section{Methods and Materials}

1. Bacterial strains: The effect of macarbomycin on the growing bacterial cells was studied with Staphylococcus aureus FDA 209P. The particulate fractions for peptidoglycan synthesis in vitro were prepared from both $S$. aureus and Escherichia coli $\mathrm{Y}-10$. The preferential effect of the antibiotic on the bacterial strains carrying episomes was studied with E. coli K12 W3630 and ML 3996. Both strains were kindly supplied by Dr. S. Mitsuhasm, Faculty of Medicine, Gunma University.

2. Media: CG medium used for $S$. aureus contained $10 \mathrm{~g}$ casamino acids, $3 \mathrm{~g} \mathrm{NaCl}$, $2 \mathrm{~g}$ glucose, $250 \mathrm{mg} \mathrm{MgSO}_{4} \cdot 7 \mathrm{H}_{2} \mathrm{O}, 11 \mathrm{mg} \mathrm{CaCl}, 1 \mathrm{mg}$ thiamine-HCl, $0.6 \mathrm{mg}$ pyridoxal$\mathrm{HCl}, 2 \mathrm{mg}$ nicotinamide, $2 \mathrm{~g} \mathrm{KH}_{2} \mathrm{PO}_{4}$ and $7.3 \mathrm{~g}$ tris per liter and was adjusted with $\mathrm{HCl}$ to $\mathrm{pH}$ 7.4. All E. coli strains were grown in nutrient-bouillon.

3. Growth of bacteria: For small scale experiments bacterial cells were grown in L-tubes, each containing $10 \mathrm{ml}$ of medium, with shaking at $37^{\circ} \mathrm{C}$. The optical density (O. D.) at $600 \mathrm{~m} \mu$ was measured with Coleman Spectrophotometer. In order to obtain the particulate fractions for in vitro synthesis of peptidoglycan, S. aureus and E. coli $\mathrm{Y}-10$ were grown on large scale in 10-liter reagent bottles with forced aeration. 
4. Biochemical measurements: To determine the amount of cellular protein, cells were washed with $5 \%$ perchloric acid and then extracted with $5 \%$ perchloric acid at $100^{\circ} \mathrm{C}$ for 30 minutes. The residue was dissolved in $1 \mathrm{~N} \mathrm{NaOH}$ and the amount of protein was measured by the method of LownY ${ }^{7}$.

Incorporation of labeled compounds was determined as follows: ${ }^{14} \mathrm{C}$-Labeled or ${ }^{3} \mathrm{H}-$ labeled compounds were added to $10 \mathrm{ml}$ cultures in L-tubes when $\mathrm{O}$. D. $(600 \mathrm{~m} \mu)$ of the cultures reached at about 0.2 . At intervals $0.5 \mathrm{ml}$ samples were removed, cold $5 \%$ trichloroacetic acid added, and the precipitates collected on membrane filters. The filters were dried and counted in a scintillation counter. Labeled compounds were obtained from Daiichi Pure Chemicals except that ${ }^{14} \mathrm{C}-\mathrm{N}$-acetylglucosamine was prepared from ${ }^{14} \mathrm{C}-$ glucosamine and acetic anhydride by the procedure of Roseman and LUDWIEG ${ }^{8}$.

${ }^{14} \mathrm{CO}_{2}$-Evolution from the cultures which received various ${ }^{14} \mathrm{C}$-labeled compounds was determined as follows: Ten-ml cultures, grown in L-tubes to O. D. of 0.2 at $600 \mathrm{~m} \mu$, were transferred into $U$-shaped tubes partitioned by a glass-filter disc in the middle. ${ }^{14} \mathrm{C}$-Labeled compounds were added as indicated and incubated at $37^{\circ} \mathrm{C}$ under aeration from the one end of the U-tube. The exhaust air was passed through the same type vessels that contained about $10 \mathrm{ml}$ of a mixture of phenethylamine and methanol $(1: 1)$. After 60 -minute incubation, the cultures were acidified by adding $2 \mathrm{ml}$ of $50 \%$ trichloroacetic acid and aeration was continued for another 60 minutes. The volume of the phenethylamine-methanol mixture was measured and the radioactivity in $1.0 \mathrm{ml}$ samples of the mixture was determined in a scintillation counter. The volume of the culture fluid was measured and $3-\mathrm{ml}$ aliquots were kept standing in ice for a while and then centrifuged for 10 minutes at $1,000 \mathrm{~g}$. The precipitates were resuspended in $3 \mathrm{ml}$ of $10 \%$ trichloroacetic acid and the radioactivity of $1.0 \mathrm{ml}$ samples of each fraction of culture fluid was determined as above and quenching was corrected by external standardization. The total radioactivity for each fraction was calculated from its volume and the corrected radioactivity of each $1.0 \mathrm{ml}$ samples.

5. Viable counts: Serial dilutions of bacterial cultures were made with $0.85 \% \mathrm{NaCl}$ and duplicate samples of the final dilutions were spread on nutrient-bouillon agar plates. Colonies were counted after overnight incubation.

6. Hemolysis: Paper discs dipped in the solution of various concentrations of macarbomycin were placed on blood agar plates and incubated at $37^{\circ} \mathrm{C}$ overnight. The plates were checked for hemolytic rings.

7. Nucleotide accumulation in cells: Cell wall precursors, accumulated in cells, were extracted and determined according to STROMINGER ${ }^{11)}$.

8. In vitro synthesis of peptidoglycan: UDP-MurNAc-L-Ala $\cdot \mathrm{D}-\mathrm{Glu} \cdot \mathrm{L}-\mathrm{Lys} \cdot{ }^{14} \mathrm{C}-\mathrm{D}-$ Ala $\cdot{ }^{14} \mathrm{C}-\mathrm{D}$-Ala was prepared by the procedure of Neuhaus and Srruve using enzymes from Streptococcus faecalis $\mathrm{R}^{14)}$. UDP-MurNAc-L-Ala $\cdot \mathrm{D}-\mathrm{Glu} \cdot \operatorname{meso} \mathrm{DAP} \cdot{ }^{14} \mathrm{C}-\mathrm{D}-\mathrm{Ala} \cdot{ }^{14} \mathrm{C}-$ D-Ala was kindly provided by Dr. K. IzAKI, Faculty of Agriculture, Tohoku University.

The particulate fractions from $S$. aureus FDA $209 \mathrm{P}$ and $E$. coli $\mathrm{Y}-10$ were obtained after grinding cells with quartz sand. After incubation, reaction mixtures were subjected to paper chromatography on Toyo No. 514 filter paper in isobutyric- $1 \mathrm{~N} \mathrm{NH}_{4} \mathrm{OH}(5: 3)$. Peptidoglycan synthesized remained at the origin of the chromatogram. Lipid intermediate formed and alanine released by the transpeptidase and carboxypeptidase activity of $E$. coli particulate fractions were detected on the filter paper by autoradiography. These spots were excised and counted in a liquid scintillation counter. The details of the above procedures were identical with that described by STRominger et al. ${ }^{13)}$

Cell walls from $S$. aureus FDA $209 \mathrm{P}$ were prepared by sonic disintegration of cells and repeated centrifugations according to the method of STruve et al. ${ }^{15}$ 


\section{Results}

\section{A. Effect of Macarbomycin on Growing Cells of S. aureus}

\section{A-1. Effect on the growth}

As shown in Fig. Ia, the growth of $S$. aureus was almost completely inhibited by $1 \mu \mathrm{g} / \mathrm{ml}$ or $10 \mu / \mathrm{ml}$ of macarbomycin after 1 hour. But when $100 \mu \mathrm{g} / \mathrm{ml}$ of the drug was added, the O.D. of the culture kept rising gradually. The phenomenon that the O.D. curve for 100 $\mu \mathrm{g} / \mathrm{ml}$ finished at a higher level than those for the lower concentrations was quite reproducible.

However, as shown in Fig. $1 \mathrm{~b}$, when the amount of protein per $\mathrm{ml}$ culture was taken as the index of the growth instead of the O.D., the final level of the growth for $100 \mu \mathrm{g} / \mathrm{ml}$ was equal to that for 1 or $10 \mu \mathrm{g} / \mathrm{ml}$. The discrepancy might be explained by the increase in the volume

Fig. 1. Effect of macarbomycin on the growth of S. aureus.

O.D. and the amount of protein per $0.3 \mathrm{ml}$ were measured on the same set of L-tubes.

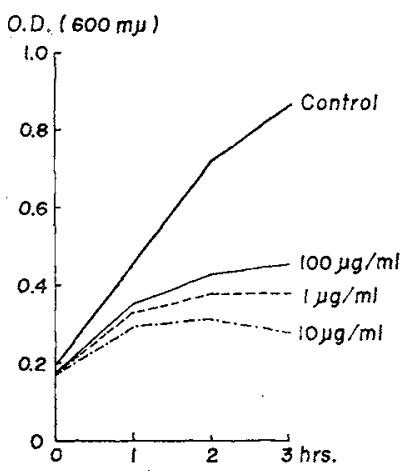

or by some morphological modification of the bacterial cells under the influence of the high concentration of macarbomycin.

A-2. Effect on the incorporation of labeled compounds

In order to examine the effects of macarbomycin on the synthesis of cellular macromolecules, the rate of incorporation of various labeled compounds into the acid-insoluble fraction of $S$. aureus was measured. Incorporation of ${ }^{14} \mathrm{C}$-casamino acids, ${ }^{3} \mathrm{H}-$ thymidine and ${ }^{3} \mathrm{H}$-uridine was only slightly inhibited by $0.2,1.0$ or $5.0 \mu \mathrm{g} / \mathrm{ml}$ of macarbomycin. The inhibition of the incorporation during 20-minute incubation with $5 \mu \mathrm{g} / \mathrm{ml}$ was as follows: ${ }^{14} \mathrm{C}$-casamino acids, $22 \%$; ${ }^{3} \mathrm{H}$-thymidine, $6 \% ;{ }^{3} \mathrm{H}$-uridine, $12 \%$. Thus neither protein nor nucleic acid synthesis could be assumed to be the primary site of action of the antibiotic. However, when ${ }^{14} \mathrm{C}$-adenine was used instead of ${ }^{3} \mathrm{H}$-thymidine or ${ }^{3} \mathrm{H}$-uridine, its incorporation during 20 -minute incubation with $5 \mu \mathrm{g} / \mathrm{ml}$ marcarbomycin was inhibited by $38 \%$ (Fig. 2). The inhibition of incorporation of ${ }^{14} \mathrm{C}$-adenine can be attributed to a secondary effect of macarbomycin which acts primarily on the peptidoglycan synthesis as described below.

Fig. 3 shows the effect of macarbomycin on the incorporation of ${ }^{14} \mathrm{C}-\mathrm{N}$-acetyl-
Fig. 2. Effect of macarbomycin on the incorporation of ${ }^{14} \mathrm{C}$-adenine.

The amount of ${ }^{4} \mathrm{C}$-adenine added was $0.01 \mu \mathrm{C}$ per $\mathrm{m} 1(1 \mu \mathrm{C} / \mu \mathrm{mole})$.

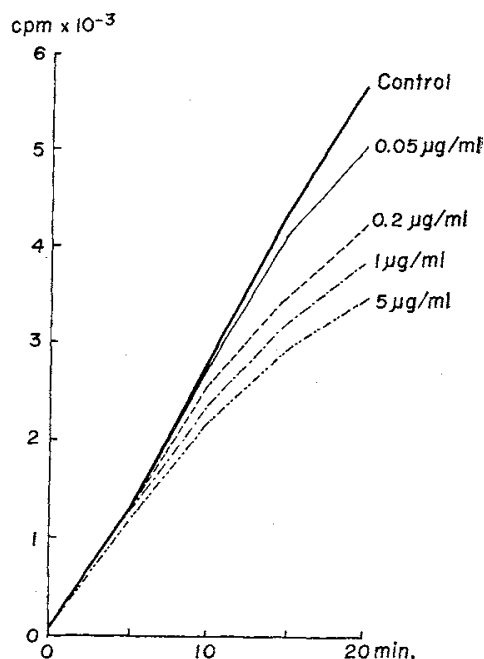


glucosamine into the acid-insoluble fraction. NAcetylglucosamine is a component of bacterial cell wall and therefore the incorporation of ${ }^{14} \mathrm{C}-\mathrm{N}$ acetylglucosamine was thought to be an index for the synthesis of cell wall. Macarbomycin inhibited markedly and quickly the incorporation of this precursor and the degree of inhibition was as much as $65 \%$ after 20 -minute incubation at $5 \mu \mathrm{g} / \mathrm{ml}$ of the antibiotic. It should be noticed that the inhibition was already significant as early as 5 minutes. The highest concentration shown in Fig. 3 is $5 \mu \mathrm{g} / \mathrm{ml}$, but no greater extent of inhibition was observed at concentrations of macarbomycin up to $100 \mu \mathrm{g} / \mathrm{ml}$, when the incubation period was limited to 20 minutes. At $0.2 \mu \mathrm{g} / \mathrm{ml}$, the degree of inhibition was about a half of that observed at $5 \mu \mathrm{g} / \mathrm{ml}$. There was apparent inhibition at a level as low as $0.05 \mu \mathrm{g} / \mathrm{ml}$. These concentrations correspond to the minimum inhibitory concentration of macarbomycin against the growth of this organism, $0.05 \sim 0.2 \mu \mathrm{g} / \mathrm{ml}$, as determined by the broth dilution method. These results strongly suggested that the primary site of action of macarbomycin is cell wall synthesis.

When ${ }^{14} \mathrm{C}-\mathrm{N}$-acetylglucosamine was replaced by the equivalent amount of ${ }^{14} \mathrm{C}$-glucosamine, there was no incorporation of the radioactivity into the acidinsoluble fraction, although the data are not shown here. It is thought that $\mathrm{N}$-acetylglucosamine was preferentially used for cell wall biosynthesis. The evolution of ${ }^{14} \mathrm{CO}_{2}$ during incubation with ${ }^{14} \mathrm{C}$-glucosamine, ${ }^{14} \mathrm{C}$ - $\mathrm{N}$-acetylglucosamine and ${ }^{14} \mathrm{C}$-glucose is shown in Table 1 together with the distribution of the radioactivity in acid-soluble and acid-insoluble fractions. Glucosamine was metabolized only slightly and mainly remained unchanged in the medium under the experimental condition.

In $S$. aureus it is known that teichoic acid is a major component of cell wall, and both teichoic acid and peptidoglycan contain $\mathrm{N}$-acetylglucosamine ${ }^{9)}$. According to PARK and $\mathrm{HANCOCK}^{10)}$, teichoic acid together with nucleic acid can be quantitatively extracted by heating in $5 \%$ trichloroacetic acid at $90^{\circ} \mathrm{C}$ for 6 minutes, while peptidoglycan remains intact. In the experiment shown in Fig. 4, the cells were labeled with 
Fig. 4. Effect of macarbomycin on the incorporation of ${ }^{14} \mathrm{C}-\mathrm{N}$-acetylglucosamine.

The conditions for labelling was the same as in Fig. 3. The cells in $0.5 \mathrm{ml}$ aliquots were precipitated in $5 \%$ TCA together with about $3 \mathrm{mg}$ (dry weight) of non-labeled cells. Hot TCA extraction was carried out as described by PARK and HANCOCK ${ }^{10}$.

a) Hot TCA-insoluble fraction

b) Hot TCA-soluble fraction

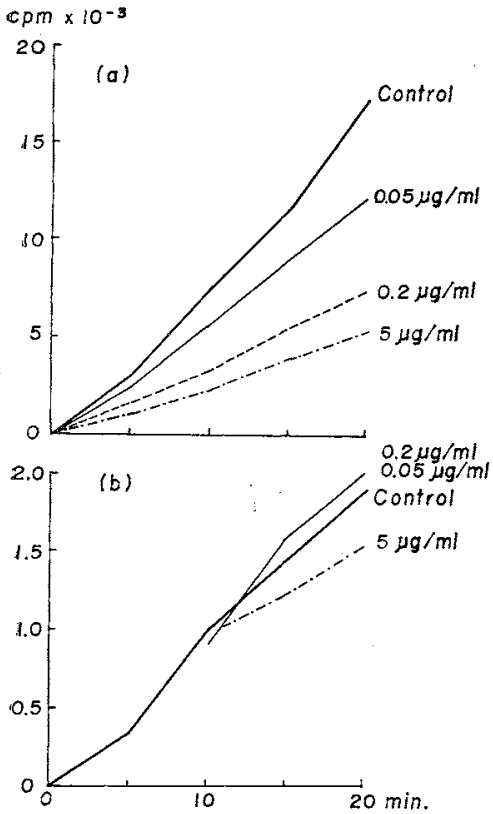

Fig. 5. Anion exchange chromatogram of cold TCA extract from macarbomycintreated cells.

The extract prepared from $500 \mathrm{ml}$ culture of macarbomycin-treated S. aureus $(10 \mu \mathrm{g} / \mathrm{ml})$ was applied to Dowex $1 \times 2$ column (C1 type, $6 \mathrm{~cm}^{3}$ ). Elution was carried out according to STROMINGER 11 : $\mathrm{A}, 0.002 \mathrm{~N} \mathrm{HCl} ; \mathrm{B}, 0.01 \mathrm{~N} \mathrm{HCI} ; \mathrm{C}$ $0.05 \mathrm{M} \mathrm{NaCl}$ in $0.01 \mathrm{~N} \mathrm{HCl} ; \mathrm{D}, 0.1 \mathrm{M} \mathrm{NaC} 1$ in 0.01 $\mathrm{N} \mathrm{HCl} ; \mathrm{E}, 0.1 \mathrm{~N} \mathrm{HCl} ; \mathrm{F}, 0.5 \mathrm{~N} \mathrm{HCl}$. Fractions of $10 \mathrm{ml}$ were collected. The peak at tube No. 24 was identified spectrophotometrically as CMP, the peaks at 30 and 34 as AMP.

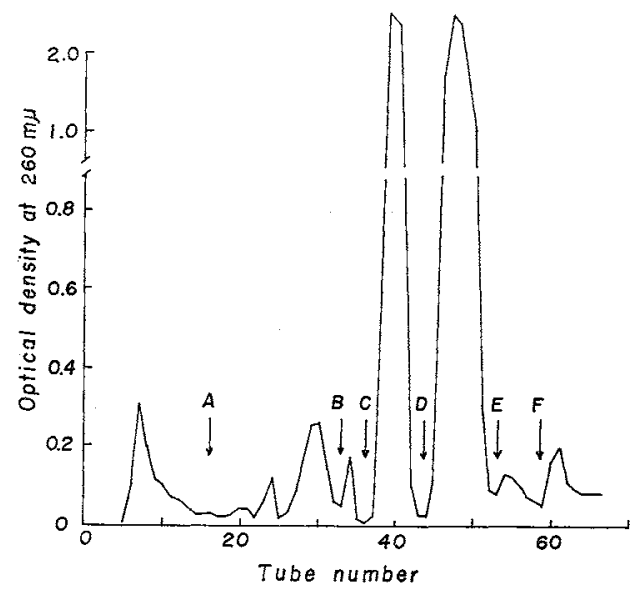

${ }^{14} \mathrm{C}-\mathrm{N}$-acetylglucosamine and then fractionated into two fractions, the hot TCA-soluble (Fig. 4b) and TCA-insoluble (Fig. 4a) fractions. It is obvious that macarbomycin has no effect on the synthesis of teichoic acid and inhibits preferentially the synthesis of peptidoglycan.

A-3. Effect on the viability of cells

Since macarbomycin is a relatively high molecular compound and its reversible dissociation was demonstrated in another paper ${ }^{1)}$, it is possible that the antibiotic forms a micelle structure and affects the lipid layer of bacterial cell membrane. In order to check the possibility that the antibiotic might affect cell membrane in addition to the synthesis of cell wall peptidoglycan, we examined its effect on the viability of cells. Viable counts of a culture started to decrease slowly when $10 \mu \mathrm{g} / \mathrm{ml}$ of the drug was added: It was reduced from $3.0 \times 10^{8} / \mathrm{ml}$ to $1.0 \times 10^{8} / \mathrm{ml}$ during 80 minute incubation. This bacteriocidal effect is very weak and it does not suggest that macarbomycin has action on cell membrane. Furthermore, the antibiotic did not cause hemolysis of red blood cells even at the concentration of $1 \mathrm{mg} / \mathrm{ml}$ in contrast to other macromolecular peptide antibiotics such as gramicidin.

\section{A-4. Nucleotide accumulation}

It has been reported that those antibiotics which inhibit cell wall synthesis, such as penicillin, vancomycin, ristocetin and bacitracin, cause an accumulation of cell wall precursors, i.e., UDP-N-acetylmuramylpeptides.

Macarbomycin was added to growing cells of $S$. aureus and the TCA extract of 
Table 2. Analysis of peak C and D.

\begin{tabular}{l|c|c|c|c}
\hline & $\begin{array}{c}\text { Peak C } \\
\mu \text { moles/ml }\end{array}$ & Ratio & $\begin{array}{c}\text { Peak D } \\
\mu \text { moles } / \mathrm{ml}\end{array}$ & Ratio \\
\hline Uridine & 0.53 & 1.00 & 0.94 & 1.00 \\
Total P & 1.15 & 2.16 & 1.74 & 1.85 \\
NAcGA & 0.54 & 1.02 & 0.91 & 0.97 \\
D-Alanine & 0.88 & 1.67 & - & - \\
Amino acid & Ala, Glu, Lys. & & Ala. & \\
\hline
\end{tabular}

Each fraction was concentrated by charcoal adsorption and elution. The analytical methods were as follows: Uridine, spetrophotometry; total phosphorus, the method described by AMES ${ }^{12)}$; $\mathrm{N}$-acetylamino sugar, the method described by STROMINGER 11); D-alanine, pyruvate was measured colorimetrically after acid hydrolysis and oxidation with D-amino acid oxidase; Amino acids, paper chromatography after acid hydrolysis.

Fig. 7. Nucleotide accumulation as a function of concentration of macarbomycin.

The cultures were kept incubated for 2 hours after the addition of macarbomycin.

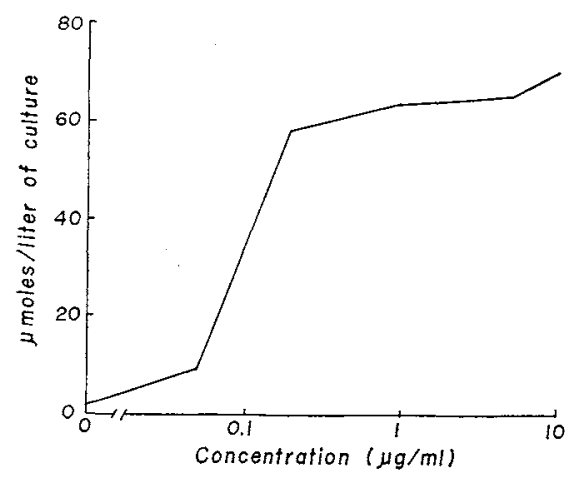

Fig. 9. Effect of macarbomycin on the peptidoglycan synthesis by $S$, aureus enzyme

The reaction condition was identical to that described for Fig. 8 except that the reaction was terminated after 4-hour incubation. The amount of peptidoglycan and intermediate was expressed as per cent of that formed in the control. The dotted line shows the dose response of peptidoglycan synthesis at the one-fourth concentration of $S$. aureus enzyme.

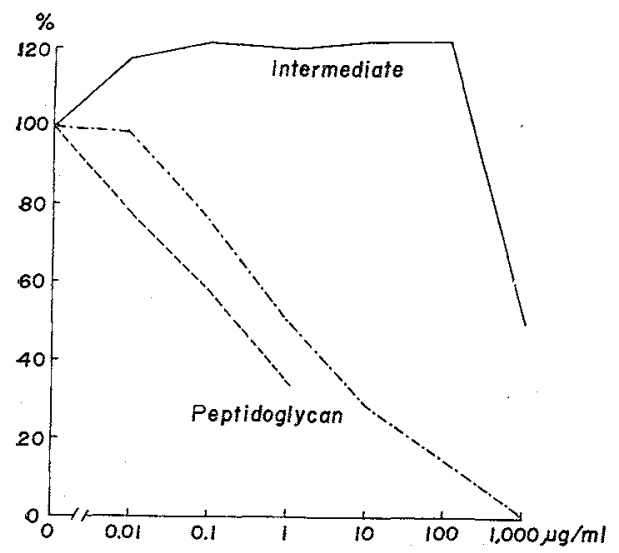

Fig. 6. Nucleotide accumulation as a function of time.

$\mathrm{N}$-Acetylamino sugar in the extract was determined and expressed as the amount in 1 liter of culture at $O . D$. $(600 \mathrm{~m} \mu)$ of 1.0. The concentration of macarbomycin was $10 \mu \mathrm{g} / \mathrm{ml}$.

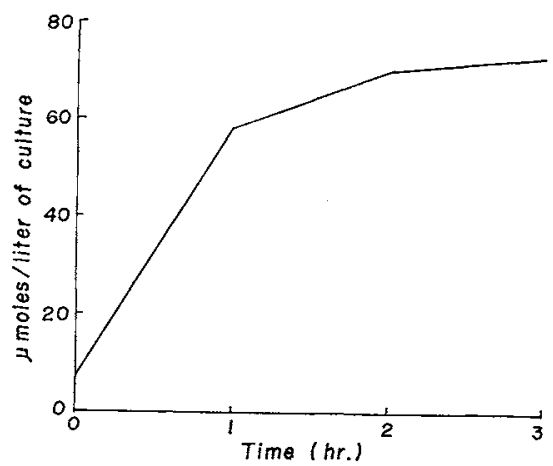

Fig. 8. Time course of peptidoglycan synthesis by $S$. aureus enzyme

The reaction mixture contained: Tris- $\mathrm{HCl} \mathrm{CpH}$ 8.6), $3 \mu$ moles ; $\mathrm{MgCl}_{2}, 0.1 \mu$ moles ; UDP-GluNAc, 12 m $\mu$ moles ; ATP, 20 mumoles ; UDP-MurNAc$x$-Ala.D-Glu.L-Lys.14C-D-Ala. ${ }^{4}$ C-D-Ala, $0.30 \mathrm{~m} \mu-$ moles $\left(6.1 \times 10^{4} \mathrm{cpm}\right)$; particulate enzyme, $135 \mu \mathrm{g}$ (as protein). Total volume was $30 \mu \mathrm{I}$. The mixture was incubated at $20^{\circ} \mathrm{C}$. The reaction was terminated by placing the tubes in a boiling waterbath.

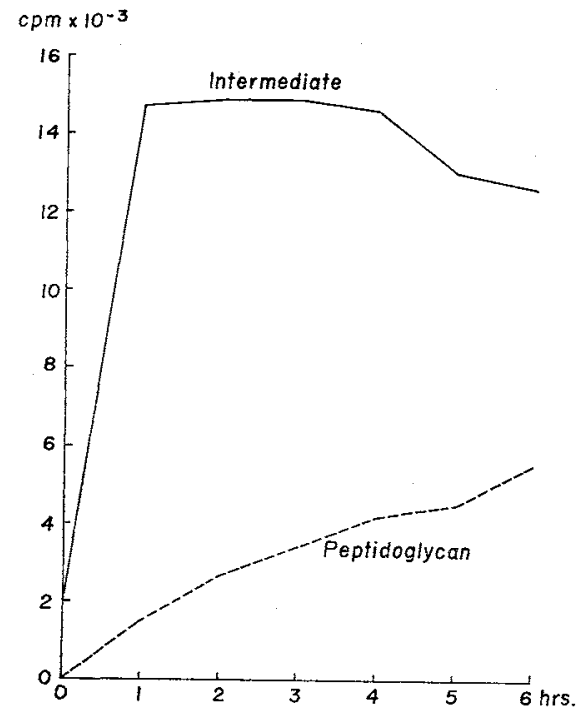

the cells was chromatographed on Dowex-1 column. The elution pattern observed was virtually identical with that obtained with penicillin $^{11)}$ (Fig. 5). Analysis of the main two peaks clearly indicated that macarbomycin also causes the accumulation of the cell wall precursors. Table 2 shows that 
Fig. 10. Effect of vancomycin on the peptidoglycan synthesis by $S$. aureus enzyme.

The procedure was identical to that described for Fig. 9.

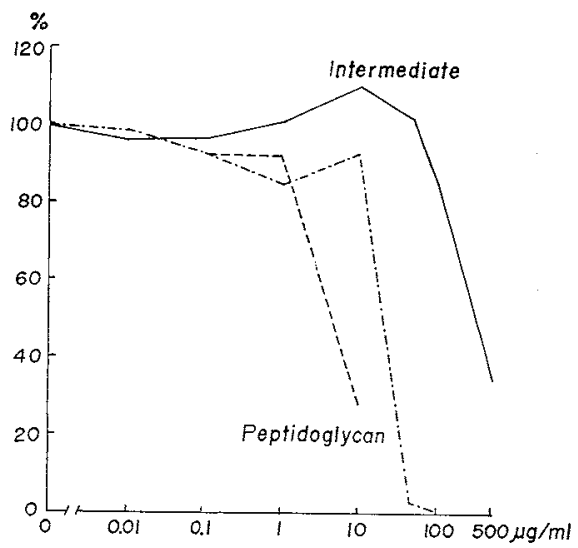

peak $\mathrm{C}$ corresponds to UDP-MurNAc-L-Ala . $\mathrm{D}-\mathrm{Glu} \cdot \mathrm{L}-\mathrm{Lys} \cdot \mathrm{D}-\mathrm{Ala} \cdot \mathrm{D}-\mathrm{Ala}$ and peak D to UDPMurNAc-L-Ala, respectively.

The nucleotides, which were measured by the content of $\mathrm{N}$-acetylamino sugar in the TCA extract, started to accumulate promptly on addition of the antibiotic and reached a plateau after 2-hour incubation (Fig. 6). The relationship between the concentration of macarbomycin and the amount of accumulated nucleotides after 2-hour incubation is shown in Fig. 7. Although the data are not shown here, the amount of accumulated nucleotides was much larger than that obtained with penicillin-treated cells.

B. Effect of Marcarbomycin on in vitro Synthesis of Peptidoglycan

As it was clearly demonstrated that the primary site of action of macarbomycin on the growing cells of $S$. aureus FDA $209 \mathrm{P}$ is the synthesis of peptidoglycan, we proceeded to examine the effect of the antibiotic on in vitro synthesis of peptidoglycan. The particulate fractions obtained from $S$. aureus FDA $209 \mathrm{P}$ and $E$. coli $Y-10$ were employed. Fig. 8 shows the kinetics of the incorporation of radioactivity into peptidoglycan and the lipid intermediate when the particulate fractions from S. aureus were incubated with UDP-MurNAc-L-Ala $\cdot \mathrm{D}-\mathrm{Glu} \cdot \mathrm{L}-\mathrm{Lys} \cdot{ }^{14} \mathrm{C}-\mathrm{D}-\mathrm{Ala} \cdot{ }^{14} \mathrm{C}-\mathrm{D}-\mathrm{Ala}$. With our enzyme from $S$. aureus, the amount of peptidoglycan synthesized was much less than that of lipid intermediate, although peptidoglycan synthesis was linear during
Fig. 11. Effect of macarbomycin on the peptidoglycan synthesis by $E$. coli enzyme.

The reaction mixture contained: Tris$\mathrm{HCl}$ (pH 7.5), 5 umoles ; $\mathrm{MgCl}_{2}, 1.25 \mu$ moles; UDP-GluNAc, 12 m $\mu$ moles ; UDP-MurNAcI-Ala.D-Glu.meso DAP.14C-D-Ala.14C-DAla, $1.2 \mathrm{~m} \mu$ moles $\left(8.0 \times 10^{4} \mathrm{cpm}\right)$; particulate enzyme, $100 \mu \mathrm{g}$ (as protein). Total volume was $35 \mu 1$. The mixture was incubated at $30^{\circ} \mathrm{C}$ for 1 hour. The amount of peptidoglycan, alanine and intermediate was the control. In the control the following values of radioactivity were obtained: peptidoglycan, $2375 \mathrm{cpm}$; alanine, $4822 \mathrm{cpm}$. intermediate, $21776 \mathrm{cpm}$.

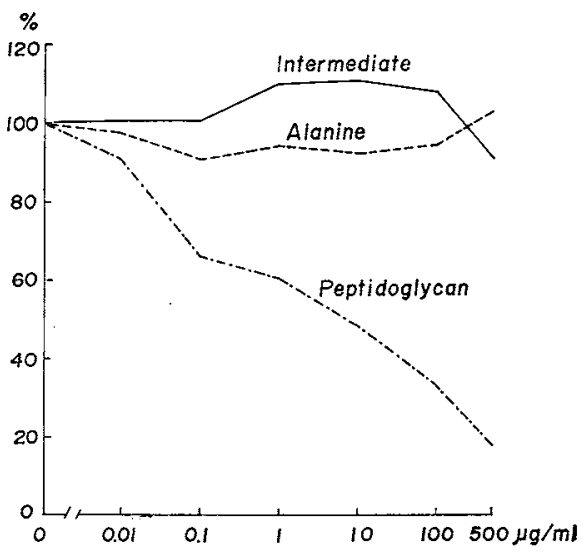

Fig. 12. Effect of vancomycin on the peptidoglycan synthesis by $E$. coli enzyme.

The procedure was identical to that described for Fig. 11.

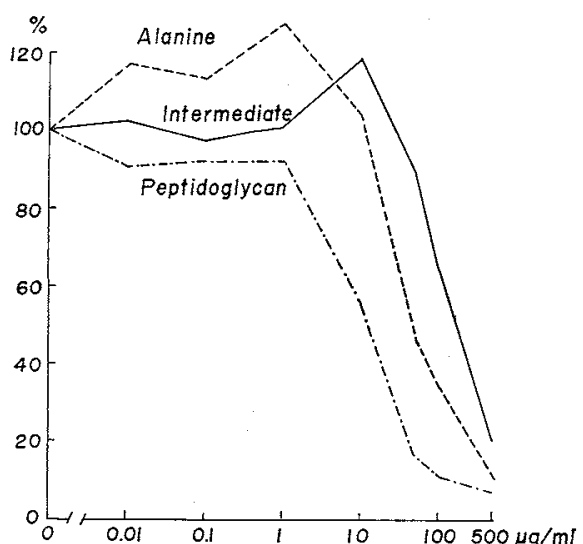
expressed as per cent of that formed in 
incubation for 6 hours. According to Strominger and his co-workers, lipid intermediate was formed very rapidly at first and then maintained at a constant level to be outstripped by the synthesis of peptidoglycan ${ }^{16)}$. The reason why with our enzyme peptidoglycan was formed at a lower rate when compared to the level of lipid intermediate is not known.

The effect of macarbomycin and vancomycin on the synthesis of peptidoglycan is shown in Fig. 9 and Fig. 10, respectively. Vancomycin is another polysaccharide antibiotic and is known to inhibit the synthesis of peptidoglycan ${ }^{17)}$. Both antibiotics evidently inhibited the reaction. In case of vancomycin the peptidoglycan synthesis was not appreciably affected at concentrations lower than $50 \mu \mathrm{g} / \mathrm{ml}$, while at or above $50 \mu \mathrm{g} / \mathrm{ml}$ marked inhibition was observed. On the contrary, macarbomycin showed a very sluggish dose-response curve. The antibiotic inhibited the synthesis of peptidoglycan to some extent at the concentration of as low as $0.1 \mu \mathrm{g} / \mathrm{ml}$ and the amount of peptidoglycan synthesized gradually decreased as the concentration of the drug was increased. However, even at a concentration of $100 \mu \mathrm{g} / \mathrm{ml}$, the inhibition was not complete and a small amount of peptidoglycan was formed. Lipid intermediate formation was stimulated by lower concentrations of the antibiotics, especially by macarbomycin, and only at very high concentrations inhibition was observed. When the amount of particulate enzyme was reduced, the sensitivities of peptidoglycan synthesis to the antibiotics increased (Dotted lines in Fig. 9 and Fig. 10).

The effect of substrate concentration on the inhibition of peptidoglycan synthesis is shown in Table 3. In our assay system the amount of UDP-MurNAc-L-Ala $\cdot \mathrm{D}-\mathrm{Glu}$. L-Lys ${ }^{14} \mathrm{C}-\mathrm{D}-\mathrm{Ala} \cdot{ }^{11} \mathrm{C}-\mathrm{D}-\mathrm{Ala}$ was far less than that of UDP-GluNAc, so the amount of the radioactive substrate was varied. The inhibition by vancomycin was reversed by increasing the concentration of the substrate, whereas macarbomycin inhibited the reaction to the same degree at different concentrations of the substrate.

Table 4 shows the effect of cell walls on the inhibition of peptidoglycan synthesis by the antibiotics. Additions of cell walls to the reaction mixture containing vancomycin reversed most of the inhibition by the antibiotic. On the contrary, the inhibition by macarbomycin was not reversed by the addition of cell walls.

Table 3. Effect of substrate concentration

\begin{tabular}{cc|c|c|c}
\hline $\begin{array}{c}\text { UDP- } \\
\text { MurNAc- } \\
\text { pentapeptide } \\
\text { (n moles) }\end{array}$ & Antibiotic & $\begin{array}{c}\text { Peptido- } \\
\text { glycan } \\
\text { formed } \\
\text { (cpm) }\end{array}$ & $\begin{array}{c}\text { Percent } \\
\text { inhibi- } \\
\text { tion }\end{array}$ \\
\hline 1 & 0.30 & & 2283 & \\
2 & 0.60 & None & 2279 & \\
3 & 0.90 & & 2050 & \\
4 & 0.30 & Macarbomycin & 1270 & 44 \\
5 & 0.60 & $(0.1 \mu \mathrm{g} / \mathrm{ml})$ & 1281 & 44 \\
6 & 0.90 & & 943 & 53 \\
7 & 0.30 & Vancomycin & 1516 & 33 \\
8 & 0.60 & $(10 \mu \mathrm{g} / \mathrm{ml})$ & 1850 & 18 \\
9 & 0.90 & & 1760 & 14 \\
\hline
\end{tabular}

The reaction conditions were identical to those described for Fig. 8 except that the reaction was terminated after 5-hour incubation and one-fourth as much enzyme was used.
Table 4. Effect of cell-wall on the inhibition by antibiotics

\begin{tabular}{ll|c|c|c}
\hline Antibiotics & $\begin{array}{c}\text { Cell- } \\
\text { wall }\end{array}$ & $\begin{array}{c}\text { Peptido- } \\
\text { glycan } \\
\text { formed } \\
\text { (cpm) }\end{array}$ & $\begin{array}{c}\text { Percent } \\
\text { inhibi- } \\
\text { tion }\end{array}$ \\
\hline 1 & None & - & 4120 & \\
2 & + & 4054 & \\
3 & Macarbomycin & - & 1094 & 73 \\
4 & $(10 \mu \mathrm{g} / \mathrm{ml})$ & + & 1089 & 73 \\
5 & Vancomycin & - & 772 & 81 \\
6 & $(50 \mu \mathrm{g} / \mathrm{mI})$ & + & 3672 & 9 \\
\hline
\end{tabular}

The reaction conditions were identical to those described for Fig. 8 except that the reaction was terminated after 5-hour incubation and that $125 \mu \mathrm{g}$ (dry weight) of cell walls was added per tube where indicated. 
Table 5. Effect of preincubation on the inhibition by macarbomycin

\begin{tabular}{|c|c|c|c|c|}
\hline Macarbomycin & $\begin{array}{l}\text { Component added } \\
\text { after preincubation }\end{array}$ & Preincubation & Incubation & $\begin{array}{l}\text { Peptidoglycan } \\
\text { formed } \\
\text { (cpm) }\end{array}$ \\
\hline 1 None & \multirow{6}{*}{ Macarbomycin } & \multirow{4}{*}{ None } & \multirow{2}{*}{$5.5 \mathrm{hr}}$. & 4293 \\
\hline $2 \quad 10 \mu \mathrm{g} / \mathrm{ml}$ & & & & 1556 \\
\hline 3 None & & & $0.5 \mathrm{hr}$. & 252 \\
\hline 4 None & & & & 4107 \\
\hline $5 \quad 1 \mu \mathrm{g} / \mathrm{ml}$ & & \multirow{5}{*}{$0.5 \mathrm{hr}}$. & \multirow{5}{*}{$5 \mathrm{hr}}$. & 2047 \\
\hline $6 \quad 10 \mu \mathrm{g} / \mathrm{ml}$ & & & & 1574 \\
\hline 7 None & \multirow{3}{*}{ Substrate } & & & 4175 \\
\hline $81 \mu \mathrm{g} / \mathrm{ml}$ & & & & 2097 \\
\hline $9 \quad 10 \mu \mathrm{g} / \mathrm{ml}$ & & & & 1495 \\
\hline
\end{tabular}

The reaction conditions were identical to those described for Fig. 8.

The data shows that macarbomycin has no affinity for cell walls in contrast to vancomycin, and it was inferred that macarbomycin might show some affinity for peptidoglycan synthetase itself. However, as shown in Table 5, preincubation of the particulate enzyme with macarbomycin did not alter the degree of inhibition.

Neither macarbomycin nor vancomycin inhibits the growth of $E$. coli even at a concentration of $100 \mu \mathrm{g} / \mathrm{ml}$, but in vitro synthesis of peptidoglycan by the particulate enzyme obtained from the same organisms is inhibited by these antibiotics at the same concentration that is required to inhibit the enzyme from S. aureus FDA 209P. The effect of marcarbomycin and vancomycin on in vitro synthesis of peptidoglycan by the particulate enzyme obtained from E. coli Y-10 is shown in Fig. 11 and Fig. 12, respectively. Again with our enzyme from $E$. coli Y-10, the amount of peptidoglycan synthesized was much less than that of lipid intermediate formed. The amount of released alanine was a little larger than that of peptidoglycan synthesized. As was the case with the enzyme from S. aureus FDA 209P, macarbomycin showed a much more sluggish dose-response than vancomycin. Furthermore, vancomycin inhibited the release of alanine at higher concentrations, but macarbomycin showed no effect on the release of alanine. It is clear that macarbomycin allows carboxypeptidase to hydrolyze the radioactive substrate without concomitant synthesis of peptidoglycan.

C. Effect of Macarbomycin on the Incorporation of ${ }^{14} \mathrm{C}-\mathrm{N}-$

Acetylglucosamine by E. coli Strain Carrying Episomes

Macarbomycin is active against Gram-positive bacteria and shows only slight activity against $E$. coli. However, it was recently reported by MissuHASHI $e$ t al. that the sensitivity of $E$. coli strains to macarbomycin is enhanced by an introduction of episomes such as $\mathrm{F}, \mathrm{R}$ and $\mathrm{T}$ factors ${ }^{18)}$. In order to check if enhanced sensitivity by the presence of episomes can be attributed to the inhibition of peptidoglycan synthesis, the effect of the antibiotic on the incorporation of ${ }^{14} \mathrm{C}-\mathrm{N}$-acetylglucosamine into the TCA-insoluble fraction was determined.

We confirmed Mitsuhashi's observation. The MIC of macarbomycin against $E$. coli K12 W 3630 was $50 \mu \mathrm{g} / \mathrm{ml}$ and that against E. coli K12 ML 3996 carrying R factor was $0.78 \mu \mathrm{g} / \mathrm{ml}$. The latter strain was also more sensitive to vancomycin: MIC against E. coli K12 ML3996 was $12.5 \mu \mathrm{g} / \mathrm{ml}$ and that against E. coli K12 W3630 was 
$100 \mu \mathrm{g} / \mathrm{ml}$. As shown in Fig. 13, macarbomycin showed no effect on the incorporation of ${ }^{14} \mathrm{C}-\mathrm{N}$-acetyl glucosamine by the strain W3630. In contrast, with the strain ML 3996 the same dose caused an apparent inhibition.

Since the incorporated radioactivity does not localize solely in peptidoglycan, it is reasonable to assume that with the strain ML3996 macarbomycin would inhibit the synthesis of peptidoglycan as the primary site of action and that the presence of episome would have modified the structure of the cell surface in such a way that the antibiotic might reach the susceptible enzyme which is responsible for the synthesis of peptidoglycan.

\section{Discussions}

Above results clearly show that macarbomycin is a specific inhibitor of peptidoglycan synthesis. The fact that in a cell-free system the inhibition can not be reversed by the addition of cell walls or by increasing the concentration of substrate, suggests that macarbomycin binds to peptidoglycan synthetase itself, rather than to cell walls or UDP$\mathrm{N}$-acetylmuramyl pentapeptide. Vancomycin is known to bind to cell walls and thus block the transfer of disaccharide unit from lipid intermediate to the growing point of the cell walls ${ }^{17,18)}$. Preincubation of the particulate enzyme with macarbomycin did not affect the degree of inhibition and so we have no concrete evidence of the binding of the antibiotic to peptidoglycan synthetase. Our particulate fraction contains both peptidoglycan synthetase and cell walls as the acceptor of the disaccharide unit. It is impossible to substantiate the notion that the antibiotic binds to peptidoglycan synthetase until we can solubilize the enzyme and examine the unit reactions of the polymerization of the disaccharide unit.

Macarbomycin is known to dissociate reversibly into subunits in methanol ${ }^{1\rangle}$. This may be related to the sluggish dose response of the antibiotic, which is in a sharp contrast with vancomycin. The dissociation might occur also in water (or when the antibiotic comes in contact with the lipid molecules of the bacterial membrane) and the resulting subunits might effectively bind to or affect peptidoglycan synthetase.

The strains of $E$. coli carrying $\mathrm{R}$ factors are known to produce $\mathrm{R}$ pili similar to $\mathrm{F}$ pili, and the pili have been considered to participate in the conjugal transfer of episomes ${ }^{20,21)}$. Mirsunashi proposed that the preferential effect of macarbomycin on the bacterial strains carrying episomes might be explained by its interaction with such specific materials as $R$ pili on the bacterial surface ${ }^{18}$. But the detailed mechanism of the preferential inhibition awaits further studies.

Studies with labeled compounds indicate that growing cells of $S$. aureus incorporate ${ }^{14} \mathrm{C}-\mathrm{N}$-acetylglucosamine far more effectively than ${ }^{14} \mathrm{C}$-glucosamine and that incorporation of $\mathrm{N}$-acetylglucosamine can be taken as an index of peptidoglycan synthesis. 


\section{References}

1) TAKahashi, S.; A. Okanishi, R. UtahaRA, K. Nitta, K. MAEDA \& H. Umezawa : Macarbomycin, a new antibiotic containing phosphorus. J. Antibiotics $23: 48 \sim 50,1970$

2) Huber, G.; U. Schacht, H. L. Weidenmuller, J. Schmidt-Thome, J. Duphorn \& R. Tschesche: Moenomycin, a new antibiotic. II. Characterization and chemistry. Antimicr. Agents \& Chemoth. $-1965: 737 \sim 742,1966$

3) Weisenborn, F. L. ; J. L. Bouchard, D. Smith, F. Pansy, G. Maestrone, G. Miraglia \& E. Meyers : The prasinomycins: antibiotics containing phosphorus. Nature 213:1092 1094, 1967

4) Meyers, E.; D. S. Slusarchyk, J. L. Bouchard \& F. L. Weisenborn : The diumycins, new members of an antibiotic family having prolonged in vivo activity. J. Antibiotics $22: 490 \sim$ 493, 1969

5) LASKIN, A. I. \& W. M. CHAN : The effects of prasinomycin and diumycin on some parameters related to cell wall biosynthesis. Proc. 6 th Int. Congr. Chemotherapy. Tokyo, 1969, pp. 223 225, Univ. Tokyo Press, Tokyo, 1970

6) Huber, G. \& G. Nesemann: Moenomycin, an inhibitor of cell wall synthesis. Biochem. Biophy. Res. Commun. $30: 7 \sim 13,1968$

7) Lowry, O. H.; N. J. Rosenbrough, A. L. Farr \& R. J. Randall : Protein measurement with the FoulN phenol reagent. J. Biol. Chem. $193: 265 \sim 275,1951$

8) Roseman, S. \& J. Ludowieg: N-Acetylation of the hexamines. J. Am. Chem. Soc. $76: 301 \sim$ 302,1954

9) Sanderson, A. R.; J. L. Strominger \& S. G. Nathenson: Chemical structure of teichoic acid from Staphylococcus aureus, strain Copenhagen. J. Biol. Chem. $237: 3603 \sim 3613,1962$

10) PARK, J. T. \& R. HANCOCK : A fractionation procedure for studies of the synthesis of cell wall mucopeptide and of other polymers in cells of Staphylococcus aureus. J. Gen. Microbiol. $22: 249 \sim 258,1960$

11) Strominger, J. L. : Microbial uridine-5'-pyrophosphate N-acetylamino sugar compounds. I. Biology of the penicillin-induced accumulation. J. Biol. Chem. $224: 509 \sim 523,1957$

12) Ames, B. N. in "Methods in Enzymology" (E. N. Neufeld and V. Ginsburg, ed.), Vol. 8, p. 115. Academic Press, New York, 1966

13) Strominger, J. L.; M. Matsuhashi, J. S. Anderson, C. P. Dietrich, P. M. Meadow, W. Kats, G. Siewert \& J. M. Gilbert in "Methods in Enzymology" (E. N. Neufeld and V. Ginsburg, ed.), Vol. 8, p. 473. Academic Press, New York, 1966

14) Nevhaus, F. C. \& W. G. Struve : Enzymatic synthesis of analogs of the cell-wall precursor. I. Kinetics and specificity of uridine diphospho-N-acetylmuramyl-L-alanyl-D-glutamyl-L-lysine : D-alanyl-D-alanine ligase (adenosine diphosphate) from Streptococcus faecalis $\mathrm{R}$. Biochemistry $4: 120 \sim 131,1965$

15) Struve, W. G.; R. K. Sinha \& F. C. Neuhaus: On the initial stage in peptidoglycan synthesis. Phospho-N-acetyl-muramyl-pentapeptide translocase (uridine monophosphate). Biochemistry $5: 82 \sim 93,1966$

16) Anderson, J. S.; M. Matsuhashi, M. A. Haskin \& J. L. Strominger : Lipid-phosphoacetylmuramyl-pentapeptide and lipid-phosphodisaccharide-pentapeptide : Presumed membrane transport intermediates in cell wall synthesis. Proc. Nat. Acad. Sci. 53:881 889, 1965

17) Sinha, R. K. \& F.C. Neuraus: Reversal of the vancomycin inhibition of peptidoglycan synthesis by cell walls. J. Bact. $96: 374 \sim 382,1968$

18) Mrtsuhashi, S.; S. Iyobe \& H. Hashimoto: Preferential inhibition of the growth of Escherichia coli strains carrying episomes. J. Antibiotics $23: 319 \sim 323,1970$

19) Best, G. K.; M. K. Grastie \& R. D. MCConnelu : Relative affinity of vancomycin and ristocetin for cell walls and uridine diphosphate-N-acetylmuramyl pentapeptide. J. Bact. 102: 476 482,1970

20) Nishimura, Y.; M. Ishibashi, E. Meyneld \& Y. Hirota : Specific piliation directed by fertility factor and a resistance factor of Escherichia coli. J. Gen. Microbiol. $49: 89 \sim 98,1967$

21) Meynell, Y.; G. G. Meynelis \& N. Datta: Phylogenetic relationships of drug-resistance factors and other transmissible bacterial plasmids. Bacteriol. Rev. $32: 55 \sim 83,1968$ 